\title{
Parenting Styles and Gender Practices of Teachers and How These Effect the Way Gifted Girls Face Adversities
}

\author{
Sandra M. W. Siregar ${ }^{\mathrm{a}}$ and Lydia Freyani Hawadi ${ }^{\mathrm{b}}$
}

${ }^{a}$ Department of Educational Psychology, Faculty of Psychology, Universitas Indonesia, Depok, Indonesia; ${ }^{b}$ Department of Educational Psychology, Faculty of Psychology, Universitas Indonesia, Depok, Indonesia

*Corresponding Author:

Lydia Freyani Hawadi

Department of Educational Psychology

Faculty of Psychology, Universitas Indonesia

Jl. Lkr. Kampus Raya, Depok, Jawa Barat

Indonesia, 16424

Tel.: +62 217270004

Email address: reni@ui.ac.id 


\title{
Parenting Styles and Gender Practices of Teachers and How These Effect the Way Gifted Girls Face Adversities
}

\begin{abstract}
The present study aims to determine the influence of the gender practices and parenting styles of teachers on the manner in which gifted girls face adversity. Gifted girls $(n=64)$ in grades 7 and 8 formed the participants for this investigation. The adversity questionnaire, the gender practice questionnaire, and the Parental Authority Questionnaire (PAQ) were the instruments of measurement used by this study. A linear regression analysis was employed in the analysis of the data. The obtained results revealed that only authoritarian parenting affects the adversity quotient of gifted girls. Authoritative and permissive parenting styles as well as the gender practices of teachers did not affect the resilience of gifted girls to the difficulties faced by them.
\end{abstract}

Keywords: adversity, gender practices, parenting styles, gifted girls.

\section{Introduction}

Women have faced many challenges and inequalities for a long time. The differentiation in their roles and the inequality they face is observable not only in the family and the community, but also in education. For example, China evinces a history of gender inequality in education. For centuries, men have been privileged in terms of education, while most women do not get opportunities of schooling (Greenhalgh, 1985). In the past three decades, China has made rapid strides to eradicate such gender differences in education, but the discrimination still prevails in rural and impoverished families (Lee, 2014). In America, parents are more aware of these differences and seek excuses to treat their children in a special way (Matsumoto \& Juang, 2013). In Saudi Arabia, education is segregated by gender and children go to single-sex schools with teachers and students sharing the same gender. The curricula of these schools differ, and schools for boys traditionally teach a more complex curriculum than schools for girls (Hamdan, 2005). This differentiation is caused by social mores that structure people according to the Sharia or Islamic law, along with strong patriarchal cultural values and traditional customs inscribed for each gender, including the separation of genders outside the home (Almutairi, 2008).

In Indonesia, Dewi Sartika and Kartini are female heroes who fought for the right to equality in education for women. In 1904, the common citizens believed that a woman's place was limited to wells, kitchens, and mattresses, a sign that a person of the female gender was only expected to perform domestic work and to fulfill the sexual needs of her husband. Instead, Dewi Sartika began the first school for native women, the Sakola Istri in Tatar Priangan. Also, according to the book Gelap-Terang Hidup Kartini, the high-born Kartini fought for her right to be able to go to school in the Netherlands like her brother, Kartono. However, she never could. When she finally received a scholarship to study in the Netherlands, Kartini had to accept a marriage proposal from the regent of Rembang. Kartini felt that there was discrimination between boys and girls in education. Girls were still considered as domestic beings whose only function was to take care of the household. 
In 2016, the Central Bureau of Statistics (Badan Pusat Statistik) announced that Indonesia's population comprised 258.71 million citizens of whom 128.72 million were women. However, according to the National Labor Force Survey (Survey Angkatan Kerja Nasional), male workers still dominate 17 employment sectors. In numerical terms, Indonesia's 45.8 million total workforce consists of 29.3 million men and 16.4 million women (Songyanan, 2018).

This role distinction or gender inequality in Indonesia is an area of concern for the United Nations Development Programme (UNDP). Education and gender equality are included in the UNDP's objectives and are summarized in the Sustainable Development Goals, also known as the Global Goals. Since 2000, educational programs have been implemented in Indonesia and it is expected that by 2030 sustainable development will be created in this domain. Although this program is not specifically aimed at gifted children, it is a struggle to apply equal education for both sexes. The UNDP's goals include education for gifted girls, so that they can obtain their right to develop their potential (United Nations Development Programme, 2018).

Bainbridge (2014) believes that gifted children cannot reach their optimum potential if they are not given an adequate educational environment. Thus, a supportive environment must be created for gifted children to achieve their full potential. The school and the home are the two environments that can support talented children, and the most important roles in the two spaces is played by the child's teachers and parents. In practice, gifted children are often discriminated by their gender.

Therefore, it is a fact that gifted girls are required to try harder and to struggle more than gifted boys to achieve their potential. They must show resilience in the face of varied obstacles to fulfill their need for achievement. Girls require a high Adversity Quotient to overcome the social prejudices that hold them back. Thus, the research questions of this study are:

1. Does a teacher's gender practice exert a significant influence on the adversity faced by gifted girls?

2. Does parenting style (authoritarian, authoritative, or permissive) significantly influence the adversity faced by gifted girls?

Does a teacher's gender practice and parenting style (authoritarian, authoritative or permissive) influence the adversity faced by gifted girls?

\section{The Adversity Quotient}

The Adversity Quotient (AQ) is the ability of a person to overcome barriers and to turn them into opportunities of success for the achievement of goals (Stoltz, 2000). Stoltz considers that an individual's intelligence quotient (IQ) and emotional intelligence (EQ) matter, but so does a person's AQ. The AQ provides an overview of a person's ability to survive in situations of difficulty and measures the degree to which they are able to resolve problems they face. High AQ scores complement a gifted child's knowledge and assure their strong qualities as achievers. 
Stoltz compares life to a climb, and the individual who lives is the climber. Climbing is defined as a forward movement toward whatever goals a person wants to achieve. There are three types of climbers: (1) quitters who stop climbing midway, (2) campers who have climbed, but are looking for a comfortable place to stop and camp, and (3) climbers who continue to climb until the goal is reached. Of the three types, a gifted girl should belong to the third category. Those who successfully apply AQ optimally in facing challenges, whether they are big or small, achieve their targets. Studies show that the AQ measurement can be a better index of achieving success than IQ, not only with regard to academic achievement, but also for other related social skills (Zhou, 2009).

Four dimensions show the attributes a person needs to improve their AQ: control, origin and ownership, reach, and endurance (CO2RE). Control measures the degree or level of command felt by a person over negative circumstances that occur. In comparison to those who score low in their AQ measures, those who have a high AQ perceive a mastery over the events that befall them. As a result, they perform more actions that result in more control.

This dimension of origin and ownership depends on a person's answers to two questions: (1) Who or what causes my difficulties? (2) To what extent do I have control over the results of my difficulties? The lower one's origin score, the higher the tendency to blame themselves, beyond the point of being constructive. The higher one's origin score, the higher the person's tendency to consider external factors to be the source of the adversity and to put themselves in perspective. Ownership measures the extent to which a person feels responsible for improving the existing circumstances. It is a gage of a person's sense of accountability and desire to take action. The higher the ownership score, the higher the chances for that person to obtain the desired result, whatever the cause. Similarly, a low ownership score reduces the person's chances of gaining results, whatever the cause.

This dimension of reach denotes an individual's perception of achievement and measures perspective, load, and stress levels. This dimension depends on the answer to the question: How far will this difficulty reach other areas of my life? The lower one's reach score, the more likely the person is to experience bad events. Conversely, the higher the reach score, the more a person is able to limit the problems that occur. Those who have high reach scores can effectively resolve their problems or limit the extent to which difficulties occur, and this ability makes them stronger and less overwhelmed with their life circumstances.

Endurance is defined as the perception of time in the event of good or bad happenings and the belief or disbelief in the persisting of the consequences of those events. Endurance is a dimension that measures hope or optimism. People with high endurance scores can achieve more prevailing success. In addition, the difficulties experienced and the causes of those obstacles are perceived by such people as short and temporary. Those who have low AQ tend to see difficulties as permanent, while those who have high AQ perceive difficulties as temporary phenomena. 


\section{The Gender Practice of Teachers}

Gender practices govern social relations and interactions between the sexes (Martin, 1992). Often gender practices are unconscious in expression (Kerr, Vuyk, \& Rea, 2012). Some studies have evinced differences in the treatment meted to students on the basis of their gender. Boys consistently get more explanations for instructions that are given to them by the teachers. They regularly get more attention from their teachers, are praised more often, and are called on more often than girls (Wellesley College Center for Research on Women, 1992; Bianco, Harris, Garrison-Wade, \& Leech, 2011). With gifted students, teachers tend to expect more and to interact more often with gifted boys than with gifted girls (Bianco, Harris, Garrison-Wade, \& Leech, 2011). A study was conducted by Baudson and Preckel (2016) on 246 school teachers (24.6\% male) from 33 schools in Germany, the majority of whom had experience teaching gifted students. According to the results of this study, boys were considered smarter than girls in gifted groups and also in groups of students with average abilities. This disparity in treatment has resulted in gifted girls being rated by teachers as having lower abilities than gifted boys and thus the children themselves believe that this is so. This type of discrimination occurs almost ubiquitously and daily in schools without the actors realizing its impact: such bias can prevent gifted girls from achieving their full potential.

Research conducted by Lavach and Lanier (1975, in Hawadi, 2010)) revealed that gifted girls in grades 7 to 10 feel an intensive fear of success. Conflict is also experienced by girls as social traditions have not yet been able to accept the public success of girls. This dichotomy between their inherent qualities of excellence and social taboos has resulted in the emergence both of a fear of failure and a fear of achievement in girl children (Hawadi, 2004).

Society hopes for women to continue to function in feminine role. However, this expectation is actually contrary to the motivation of girls who desire to succeed in all respects. Further, the social discrimination also directly becomes a reason why women test higher on anxiety scores than men. Therefore, while only motivation can determine whether or not the achievement of goals is worthy, women generally choose to inhibit their motivation to succeed. (Hawadi, 2010).

In the debate about women and higher education at the World Conference on Higher Education (WHCE) held in Paris in 1998, Kearney (2000) asserted that it has long been known that there are some obstacles that make it difficult for women to develop, namely:

1. Limited access to education, especially in further studies.

2. Discrimination with regard to employment, especially in job agreements and promotions.

3. Pressure to execute both domestic and professional roles.

4. Family attitude.

5. Interruption in career.

6. Cultural stereotypes.

7. Being exiled from the male-dominated managerial culture (and the refusal to recognize women in managerial positions). 
8. The prevalence and spread of the glass-ceiling syndrome and secrecy in progression practices.

9. No adequate policies and laws to protect women's rights.

10. All the obstacles above were used as dimensions to ascertain and measure the gender practices of teachers.

\section{Parenting Styles}

Darling \& Steinberg (1993) define parenting style as the degree of warmth and demand that can represent the quality of parent and child interactions and that becomes an important determiner for the development of cognition and meaning systems of children in relation to studying and to school. Parenting patterns may be determined by two important elements, parental responsiveness, and the degree of parental demand (Ishak, Low, \& Lau, 2011).

According to Diana Baumrind (1966), three main parenting styles may be observed: authoritarian, authoritative, and permissive. The classification of these three patterns is based on the attributes of parental control, responsibility, democratic communication, and nurturing. Baumrind observes that parents with an authoritarian parenting style tend to be rigid and like to be in full control. Such parents provide a well-organized and structured environment with clear rules (Darling, 1999). They (parents) tend to demand obedience from their child and if there is non-compliance, they are likely to impose a penalty without explaining why the punishment is given. Parents who have this parenting style are very demanding but are low in responsiveness. In other words, they ask a lot from their children without offering them much warmth or responding to the needs of the children.

Like parents with the authoritarian parenting style, those who practice authoritative parenting also have high expectations and are equally demanding. However, authoritative parents want to respond to their children's needs. They are also flexible, willing to listen, provide advice, and are also highly responsive. Children with authoritative parents generally show positive outcomes. They are independent, they have high self-esteem, and are popular with their friends. Children who grow up with authoritative parents are happy, energetic, self-confident, and are liked by others in their environment; they can also make friends easily, show selfcontrol, and are concerned about the rights and needs of others (Baumrind, 1966).

Parents with a permissive parenting style provide a lot of warmth but do not set adequate limits. They allow their children to do what they want, and these children can grow up without understanding that the community will limit their behavior. They are high in responsiveness but demand very little from their children. Therefore, children with permissive parents often grow up frustrated because they are unable to meet the expectations of the community. As a result, such children can become impulsive, exert less self-control, and do not to have experience in meeting social expectations and desires from them. This inability makes it difficult for such children to adapt to social life as adults. Children who grow up with this parenting style also tend to be selfish, unmotivated, impulsive, and rebellious (Baumrind, 1966). 
Some studies have proved that parents discriminate between their children on the basis of their gender. Different styles of parenting evince different results in levels of achievement obtained by the children. The success of gifted girls can be noted from the manner in which they strive to get what they want.

\section{Methods}

\section{Participants}

64 gifted girls in grades 7 and 8 formed the participants of this investigation. The school pioneered the acceleration program, and is currently the organizer of a credit program (SKS system). Students are tested for academic achievement, conversation, and basic computer ability before they are enrolled. They are also administered a psychological examination and are interviewed before they are registered. The results of the psychological test stated that the participating students were categorized as gifted students.

Questionnaires were distributed to the 64 gifted girls after obtaining the permission of the school principal. Informed consent was obtained from the participants and they were assured of the confidentiality of their responses and were told that the information obtained from them would only be used for research purposes. The informed consent form also contained a description of the research and its objectives and there were no negative reactions from the participants with regard to their involvement in this study.

\section{Measurement}

Data were collected at the school. The gifted girls were asked to fill in the AQ questionnaire, the Parental Authority Questionnaire (PAQ), and the gender practice questionnaire. In this study, the researcher did not use Stoltz's AQ questionnaire because it was an online instrument that was actively timed and because the instrument was intended for people aged 18 years and more. Also, the instrument was in English. Considering the young age of the participants, the convenience factor, and the avoidance of misunderstandings due to language constraints, the researcher created an AQ questionnaire. The items in this instrument were arranged based on Stoltz's dimensions pertaining to the AQ: control, origin and ownership, reach, and endurance.

The researcher also employed a modified version of the PAQ to measure the perception of their parents' parenting styles by the gifted girls. The PAQ was developed by John R. Buri in 1991 and was compiled based on Diana Baumrind's parenting styles theory. The PAQ was translated and adapted to Indonesia while retaining its existing concepts. Many studies on parenting and related outcomes did not distinguish between the roles of the father and the mother. In general, participants are asked to report their parents' attitudes and behaviors (combination of father and mother) (Park \& Bauer, 2002). Meanwhile, other studies have asked participants to report their parents' parenting separately (father or mother only), and have then averaged the ratings of both (Steinberg, Blatt-Eisengart, \& Cauffman, 2006). Both of these approaches produce a measure of parenting that is generally accepted by participants; however, they cannot legitimately represent the varying gender roles played by parents and 
they can hide the differential attitude of each parent. In this study, gifted girls were asked to report their parents' attitudes and behaviors (a combination of father and mother). However, at the end of the questionnaire the participants were asked about which parent they had imagined when filling out the questionnaire: their father or their mother.

The gender practice questionnaire for teachers was designed on the debate on women and higher education at the WHCE in Paris (1998).

After the data were collected, a linear regression analysis was used to ascertain the presence or absence of a relationship and to determine the direction of the relationship between two or more variables. This study used the quantitative method in a non-experimental investigation. All three measuring instruments have passed the requisite validity and reliability tests and are feasible for data retrieval.

\section{Results}

\section{General Description of the Participants}

Table I. Descriptive Data of Participant's Age

\begin{tabular}{ccc}
\hline Age & Frequency & Percent \\
\hline 11 & 5 & 7.8 \\
12 & 36 & 56.3 \\
13 & 21 & 32.8 \\
14 & 2 & 3.1 \\
Total & 64 & 100 \\
\hline
\end{tabular}

Table 1 shows outlines the participant composition based on the age of the gifted girls. The ages of the participating gifted girls ranged from 11 to 14 years. 5 girls $(7.8 \%)$ were 11 years old, $36(56.3 \%)$, were aged 12, 21 girls $(32.8 \%)$ were 13 years old, and only 2 participants $(3.1 \%)$ were aged 1 years.

Table II. Descriptive Data of Participants' Grade in Education

\begin{tabular}{ccc}
\hline Class & Frequency & Percent \\
\hline 7 & 41 & 64.1 \\
8 & 23 & 35.9 \\
Total & 64 & 100 \\
\hline
\end{tabular}

This study was conducted on gifted girls in grades 7 and 8. Table 2 depicts the composition of participants based on their school grade. There were 41 talented girls $(64.1 \%)$ were in $7^{\text {th }}$ grade, while $23(35.9 \%)$ participants were in the $8^{\text {th }}$ grade.

Table III. Participant's Gifted Type

\begin{tabular}{lll}
\hline \multicolumn{1}{c}{ Category } & Frequency & Percent \\
\hline Quitters & 0 & 0 \\
Campers & 15 & 23.4 \\
Climbers & 49 & 76.6 \\
Total & 64 & 100 \\
\hline
\end{tabular}


Table 3 above displays that the majority of gifted girls were climbers ( 49 people), while the rest (15 people) were campers. There were no quitters among the participants.

Table IV. Parental Figure of Participant's Choice in Answering PAQ

\begin{tabular}{lll}
\hline \multicolumn{1}{c}{ Parents } & Frequency & Percent \\
\hline Father & 12 & 18.8 \\
Mother & 52 & 81.3 \\
Total & 64 & 100 \\
\hline
\end{tabular}

As mentioned before, participants were asked to record at the end of the PAQ which parent they had imagined when filling out the questionnaire, the father or the mother. Table 4 shows that the majority of the gifted girls imagined their mother (52 people) and only 12 participants imagined their father.

\section{Linear Regression Analysis}

Table V. The Result of Linear Regression Analysis

\section{Coefficients $^{\mathrm{a}}$}

Model Unstandardized Coefficients Standardized Coefficients

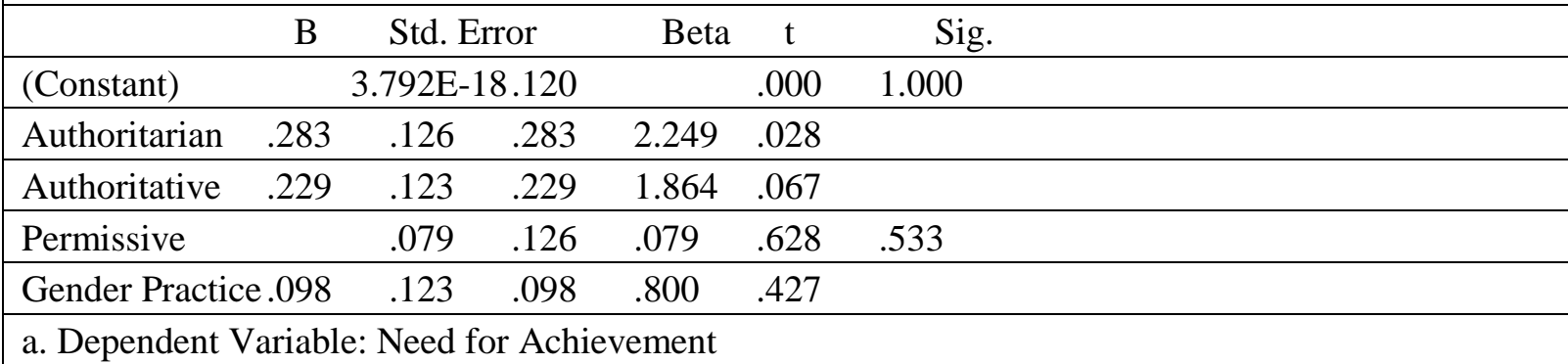

The coefficient table (Table 5) shows the effect of the significance between the variables. The criteria for the results of this regression analysis are as follows: if the value of significance is less than $0.05(\mathrm{p}<0.05)$, the independent variables exert a significant effect on the dependent variable. However, if the value of the significance is greater than 0.05 ( $p>0.05)$, the independent variables do not significantly influence the dependent variable. In this study, only authoritarian parenting, which is equal to 0.028 ( $\mathrm{p}<0.028)$, was found to fulfill the criteria for the significance. This result implies that this parenting style exerts a significant influence on the AQ of gifted girls. While authoritative, permissive, and teacher's gender practices do not significantly impact the AQ.

\section{ANOVA}

Table VI. The Result of ANOVA Analysis

\begin{tabular}{cc|c|c|c|c|c}
\hline & Model & Sum of Squares & df & Mean Square & F & Sig. \\
\hline 1 & Regression & 8.760 & 4 & 2.190 & 2.382 & $.062^{\mathrm{b}}$ \\
& Residual & 54.240 & 59 & .919 & & \\
& Total & 63.000 & 63 & & & \\
\hline
\end{tabular}

${ }^{a}$ Dependent Variable: Adversity Quotient

'Predictors: (Constant), Gender Practice, Authoritarian Parenting Style, Parenting Style Authoritative, Parenting Style Permissive. 
Table 6 depicts the level of significance or linearity of regression. The criteria for the results of this regression analysis were: if the value of the significance is smaller than $0.05(\mathrm{p}<0.05)$, the regression mode is linear. However, if the value of the significance is greater than 0.05 ( $>0.05)$, the regression model is not linear. The significance value obtained in this study was $=0.62$, which is greater than the established significance level $(p>0.05)$. Hence, the regression model is not significant, i.e., the linear regression model does not meet the linearity criteria.

\section{Discussion and Conclusion}

The results of the regression analysis evinced that the gender practices of teachers do not exert a significant effect on the adversity faced by gifted girls. This is not aligned with the results of the research conducted by Siegle and Reis (1998) and also many other researchers. Siegle and Reis (1998) found that although teachers saw gifted girls as trying harder and producing better quality output, they still gave higher grades to gifted boys. There is no visible gender practice evidenced by teachers toward gifted girls. Hence, the adversity experienced by gifted girls is not affected. With regard to gender, however, it was found that males exhibited higher control over adversity and stronger analytical capability than females (Hema \& Gupta, 2015).

The authoritarian parenting style was proved significantly influence the toughness of gifted girls. Nevertheless, this result is not congruent with Ritter's (2005). research results, which revealed that parents who apply authoritative parenting are associated with highly resilient children while authoritarian and permissive parenting styles are more often associated with low resilience in children. An authoritarian upbringing is seen as a positive style in Asia which largely adheres to collectivism (Tay \& Tam, 2010). The results of the present study evidence that the relationship between parenting and child outcomes is inconsistent in different cultures. In countries in Asia, the culture encourages dependency, unity as a group, and social hierarchy (Wang \& Leichtman, 2000). Further, even though more parents apply authoritative parenting in Western cultures, Asian parents tend to apply authoritarian parenting (Rauf \& Ahmed, 2017). Perhaps authoritarian parenting requires children to follow the rules and this adherence make talented girls more resilient. The authoritarian parenting style also in line with the tiger parenting concept introduced by Amy Chua.

Although a lot of the scholarly literature claims that authoritarian parenting negatively influences children in terms of achievement, it turns out that this parenting style is still practiced by parents. The results of research conducted by Ishak, Low \& Lau (2012), note that in addition to authoritative parenting, authoritarian parenting is still practiced by parents as the primary style of raising children in China.

The gender practices of teachers and parenting styles have not been shown to simultaneously influence the toughness of gifted girls. This result is in line with the summary model table that shows that the correlation between the three variables is weak. There are other factors to the tune of $86.1 \%$ outside of gender practice and parenting that influence the toughness of gifted girls. 
From the additional results of participant categorization based on Stoltz's theory, it was found that 49 people (76.56\%) belong to the climber category. These results seem to emphasize that the gender practices of teachers and parenting styles (authoritative and permissive) do not affect the resilience of gifted girls. They remain strong in facing the challenges they experience both at school and at home. However, 15 gifted girls are included in the camper category $(23.44 \%)$ and they have the potential of being able to enter the climber group. According to Stoltz (2000), a person's AQ can be honed so that those who have low AQ can change their scores to high given time and effort.

Other results pertaining to the parent imagined by the girls when filling the PAQ revealed that the majority imagined the parenting style applied by their mothers $(81.3 \%)$. These results indicate that participants are more exposed to parenting by their mothers. When further discussed, and when participants were asked to report on the work of their mothers, $60.9 \%$ of gifted girls wrote that their mothers were home makers. In performing this role, mothers tend to have steady interactions during the development of their child, and thus have a higher probability of passing on values and implementing their goals $(\mathrm{Li}, \mathrm{Costanzo}$, \& Putallaz, 2010). This aspect is also derived, at least in part, from the socio-cultural orientation of both mothers and children (Newman \& Newman, 2015).

\section{Limitations}

This research project acknowledges several limitations:

1. Time restrictions caused this study to be conducted only on gifted girls in one school.

2. There is limited information about schools in Jakarta that incorporate the credit system (SKS).

3. There is a paucity of preliminary studies on the topic. Hence, the available measuring instruments did not describe what to measure.

\section{Suggestions}

The following are some methodological suggestions that may be considered for future research on the subject:

1. A preliminary study should be conducted to ascertain the phenomena related to the research variables that are actually occurring in the field.

2. Data, especially pertaining to gender practices, should be collected from some schools with diverse backgrounds so that the results of the study are neutral (not influenced by religion). In addition, larger numbers of participants should be involved so that the results of the study better describe the actual phenomena.

3. Future studies should be conducted not only in big cities, but also in small towns so that a comparative analysis of the traditional perspective of people in small cities who still cannot accept the success of women can also be taken into account.

4. Further research should also draw comparisons of gender practices claimed by teachers raise against the gender practices felt by children. 
Following are some practical suggestions based on the results of research that can be applied in various contexts:

1. The results of this study are expected to bZe useful for schools, especially secondary schools that have gifted girls, in order to address the gender practices of teachers so as not to influence the gifted girls' need for achievement.

2. The results of this study are also expected to become a reference for the education of future teachers so that prospective educators are trained not to discriminate between students on the basis of gender and to provide future teachers the deep rooted understanding that each child has its own potential regardless of gender. This attitude should apply not merely to the gifted students, but to all students in general.

3. The results of the study can also provide a guideline for parents to ascertain their own parenting style so they can enhance their contribution to their children's AQ and help in the fulfillment of the potential shown by their children.

\section{References}

Almutairi, N. H. (2008). The influence of educational and sociocultural factors on the learning styles and strategies of female students in Saudi (Doctoral dissertation). University of Leicester, Leicester.

Bainbridge, C. (2014). Educational options and issues of gifted children. Retrieved from http://giftedkids.about.com/od/educationoptions/u/education.htm.

Baumrind, D. (1966). Effects of authoritative parental control on child behavior. Child Development, 37, 887907.

Baudson, T. G., \& Preckel, F. (2016). Teachers' conceptions of gifted and average-ability students on achievement-relevant dimensions. Gifted Child Quarterly, 60, 212-225.

Bianco, M., Harris, B., Garrison-Wade, D., \& Leech, N. (2011). Gifted girls: Gender bias in gifted referrals. Roeper Review, 33, 170-181.

Darling, N. (1999). Parenting styles and its correlates. ERIC Document Reproduction Servive.

Darling, N., \& Steinberg, L. (1993). Parenting style as context: An integrative model. Psychological bulletin, 113(3), 487.

Greenhalgh, S. (1985). Gender stratification: The other side of 'Growth with Equity' in East Asia. Population and Development Review. 11, 265-314.

Hamdan, A. (2005). Women annd education in Saudi Arabia: Challenges and achievements. International Education Journal, 6, 42-64.

Hawadi, R. A. (2004). Akselerasi: AZ informasi program percepatan belajar dan anak berbakat intelektual. Jakarta: Grasindo.

Hawadi, R. A. (2010). Menguatkan Bakat Anak. Jakarta: PT Gramedia Widiasarana Indonesia.

Hema, G., \& Gupta, S. M. (2015). Adversity quotient for prospective higher education. The International Journal of Indian Psychology, 2, 49-64.

Ishak, Z., Low, S. F., \& Lau, P. L. (2012). Parenting style as a moderator for students' academic achievement. Journal of Science Education and Technology, 21, 487-493.

Kearney, M. L. (Ed). (2000). Women, power and the academy: From rhetoric to reality. Berghan Books.

Lavach \& Lanier. (1975). In R. A. Hawadi (2010), Menguatkan Bakat Anak. Jakarta: PT. Gramedia Widiasarana Indonesia.

Kerr, B. A., Vuyk, M. A., \& Rea, C. (2012). Gendered practices in the education of gifted girls and boys. Psychology in the Schools, 49, 647-655.

Lee, M. H. (2014). Schooling and industrialization in China: Gender differences in school enrollment. Comparative Education Review, 58, 241-268. 
Li, Y., Costanzo, P. R., \& Putallaz, M. (2010). Maternal socialization goals, parenting styles, and socialemotional adjustment among Chinese and European American young adults: Testing a mediation model. The Journal of Genetic Psychology, 171, 330-362.

Martin, P. Y. (1992). Gender, interaction, and inequality in organizations. In C. L. Ridgeway (Ed.), Gender, interaction, and inequality (pp. 50-80). New York: Springer-Verlag.

Matsumoto, D., \& Juang, L. (2013). Culture and psychology. Wadsworth: Cengage Learning.

Newman, B. M., \& Newman, P. R. (2015). Theories of human development. New York: Psychology Press.

Park, H-S. \& Bauer, S. (2002). Parenting practices, ethnicity, socioeconomis status and academic achievement in adolescence. School Psychology International, 23, 386-396.

Rauf, K., \& Junaid, A. (2017). The relationship of authoritarian parenting style and academic performance in school students. Pakistan Journal of Psychology, 48.

Ritter, E. N. (2005). Parenting styles: Their impact on the development of adolescent resiliency. (Doctoral dissertation). Capella University, Minneapolis.

Siegle, D., \& Reis, S. (1998). Gender differences in teacher and student perceptions of gifted students' ability and effort. Gifted Child Quarterly, 42, 39-47.

Songyanan, Z. (2018). Perempuan Indonesia jangan takut kata orang. Retrieved from https://tirto.id/perempuan-indonesia-jangan-takut-kata-orang-cP1i

Steinberg, L., Blatt-Eisengart, I., \& Cauffman, E. (2006). Patterns of competence and adjustment among adolescence from authoritative, authoritarian, indulgent, and neglectful homes: A replication in a sample of serious juvenile offenders. Journal of Research on Adolescence, 16, 47-58.

Stoltz, P. G. (2000). Adversity quotient: Mengubah hambatan menjadi peluang. Jakarta: Gramedia Widiasarana Indonesia.

Tay, E. L., \& Tam, C. L. (2010). The relationship between perceived parenting styles and stress levels among Malaysian secondary school students. Sunway Academic Journal, 7, 89-104.

United Nations Development Programme. (2018). Goal 4: Quality education. Retrieved from http://www.undp.org/content/undp/en/home/sustainable-development-goals/goal-4-qualityeducation.html.

Wang, W., \& Leichtman, M. D. (2000). Same beginnings, different stories: A comparison of American and Chinese children's narratives. Child Development, 71, 1329-1346.

Zhou, H. (2009). The adversity quotient and academic performance among college students at St. Joseph's College, Quezon City (Doctoral dissertation). University Kebangsaan, Malaysia. Retrieved from www.peaklearning.com. 